\title{
Universiteit
}

Leiden

The Netherlands

\section{Reforming the UN Security Council in Pursuance of} Collective Security

Schrijver, N.J.

\section{Citation}

Schrijver, N. J. (2007). Reforming the UN Security Council in Pursuance of Collective Security. Journal Of Conflict And Security Law, 12(1), 127-138. Retrieved from https://hdl.handle.net/1887/12562

Version: $\quad$ Not Applicable (or Unknown)

License: $\quad$ Leiden University Non-exclusive license

Downloaded from: https://hdl.handle.net/1887/12562

Note: To cite this publication please use the final published version (if applicable). 
Journal of Conflict \& Security Law @ Oxford University Press 2007; all rights reserved. For permissions, please e-mail: journals.permissions@oxfordjournals.org doi: $10.1093 / \mathrm{jcsl} / \mathrm{krm} 003$

Advance Access published on April 18, 2007

\title{
Reforming the UN Security Council in Pursuance of Collective Security
}

\author{
Nico Schrijver*
}

\begin{abstract}
In many circles, the most ideal composition of the UN Security Council is a popular subject of discussion, which, by now, could easily be turned into a party game. Such discussions have generated a host of ideas on the most suitable composition of the Council, taking into account geopolitical realities. Notwithstanding all of this, the September 2005 World Summit could only agree to disagree on the issue of Security Council reform as evidenced by the notably vague paragraph requesting the General Assembly to 'review progress' on this matter by the end of $2005 .{ }^{1}$ This article purports to assess the need for, and modalities of, Security Council reform. Obviously, the most appropriate size and composition of the Security Council depends on its tasks. This issue will be addressed in Section 1. The second section highlights the Charter criteria for the composition of the Council, while the third section reviews the various reform proposals. Lastly, Section 4 discusses some alternative ideas and concludes with some final observations.
\end{abstract}

\section{The Functions and Powers of the UN Security Council}

Article 24 of the UN Charter vests the Security Council with the primary responsibility for the maintenance or restoration of peace and security. Its powers thereto, are specified in Chapter VI with respect to pacific settlement of disputes and in Chapter VII with respect to mandatory action in case of a threat to peace, breach of the peace and act of aggression. There can be little doubt that the founding fathers wanted to establish a principal organ with mandatory and supranational powers, different from the lame-duck Council of the League of Nations. Therefore, in Article 24 of the Charter of the United Nations the Council was vested with the primary responsibility for the maintenance of peace and security, and in Article 25, all members agreed 'to accept and carry out' the

* Professor of Public International Law, Leiden University, The Netherlands. E-mail: n.j.schrijver@law.leidenuniv.nl

1 'We support early reform of the Security Council - an essential element of our overall effort to reform the United Nations - in order to make it more broadly representative, efficient and transparent and thus to further enhance its effectiveness and the legitimacy and implementation of its decisions. We commit ourselves to continuing our efforts to achieve a decision to this end and request the General Assembly to review progress on the reform set out above by the end of 2005.' World Summit Outcome Document, 16 September 2005, A/RES/60/1, para. 153. However, see also J-P. Cot, 'Reforming the Security Council: Is There a Hidden Agenda?', in N. M. Blokker and N. J. Schrijver (eds.), The Security Council and the Use of Force (2005) at 269-79. 
decisions of the Council. Furthermore, in the Council of the League of Nations decision-making required unanimity, thus providing each member, de facto, with a right of veto. ${ }^{2}$ In contrast, the UN Charter introduced majority voting for the Security Council, with a right of veto for five members only. ${ }^{3}$

Initially, the Council was primarily, if not exclusively, concerned with military threats to, or breaches of, the peace. Gradually and under the influence of normative resolutions as well as political pressure of the General Assembly, the Council expanded its interpretation of the concept of the threat to peace, acknowledging that this could also result from a refusal to change a status quo widely considered to be intolerable, as for example, the denial of the right to self-determination and mass and flagrant violations of human rights. ${ }^{4}$ After the end of the Cold War, the Council further expanded the concept of threat to peace to include situations such as a massive flow of refugees across international frontiers, ${ }^{5}$ and - more recently - acts of international terrorism ${ }^{6}$ and the proliferation of weapons of mass destruction. ${ }^{7}$ The Council has also declared that "non-military sources of instability in the economic, social, humanitarian and ecological fields' ${ }^{8}$ can possibly constitute threats to peace, although it has not yet made a determination of this kind in practice.

2 Article 5, para. 1 of the Covenant of the League of Nations, stipulated that '. . . decisions at any meeting of the Assembly or of the Council shall require the agreement of all the Members of the League at the meeting'. Covenant of the League of Nations, 28 June 1919, 13 AJILs Sup. 128, 112 BFSP 13.

3 Article 27, paragraph 3, of the Charter requires a majority of nine out of 15 votes (before 1965 , it was seven out of 11) for the adoption of decisions on non-procedural matters, including 'the concurring votes of all permanent members'. In order to avoid a constant paralysis during the Cold War, an early practice emerged that an abstention by one or more permanent members would not block the adoption of a legally valid decision by the Council. In its Namibia Opinion, the International Court of Justice confirmed this practice '. . . as not constituting a bar to the adoption of resolutions'. See Legal Consequences for States of the Continued Presence of South Africa in Namibia (South West Africa) notwithstanding Security Council Resolution 276 (1970), Advisory Opinion, ICJ Rep. 1971, 16, at 22, para. 22.

4 The Council determined that the situation in Southern Rhodesia and the continued arms supplies to apartheid South Africa constituted threats to peace and ordered coercive measures, in the form of comprehensive economic sanctions (S/RES/232, 16 December 1966 and S/RES/253, 29 May 1968) and an arms embargo (S/RES/418, 4 November 1977) respectively.

5 This was the Council's determination in the context of Iraq's repression of its Kurdish populated areas. See S/RES/688, 5 April 1991. See N. J. Schrijver, 'Sovereignty versus Human Rights? A Tale of UN Security Council Resolution 688 (1991) on the Protection of the Kurdish People', in M. Castermans, F. van Hoof and J. Smith (eds.), The Role of the Nation-State in the 21st Century (1998) 347-357.

6 S/RES/1368 and 1373, 12 and 28 September 2001 and subsequent anti-terrorism resolutions.

7 S/RES/1467, 18 March 2003.

8 See statement by the president of the Security Council on the occasion of a meeting held at the level of Heads of State and Government on 31 January 1992, UN doc. S/23500. 
While the Security Council initially made its determinations in a countryor conflict-specific situation, after September 11th it started to do so also in a general sense, finding for instance, that terrorist acts, the financing of these, and the failure to deny terrorists access to certain weapons, all constitute on-going, open-ended threats to the peace - i.e. threats that are neither geographically nor temporally limited. ${ }^{9}$ In response to these threats, the Council initiated a new practice by adopting binding resolutions under Chapter VII imposing measures of general, rather than situation- or country-specific nature. ${ }^{10}$ These resolutions purport to make general law for all states, showing that the Council took up a quasi-legislative role which hitherto was considered the prerogative of the General Assembly only. ${ }^{11}$ As neatly explained by a recent commentator: 'This is action that is binding, backed by the possibility of real coercive sanction, affecting all relevant actors, and capable of repeated application across time in comparable instances.' $^{12}$

The end of the Cold War brought about other changes in the modus operandi of the Council. The Council started to explore new avenues for discharging its special responsibilities in the field of peace and security by, for instance, creating the United Nations Compensation Commission in the aftermath of the Second Gulf War $^{13}$ or by establishing the two ad hoc international criminal tribunals, one for the former Yugoslavia (ICTY) ${ }^{14}$ and another for Rwanda (ICTR). ${ }^{15}$ The Council also drastically reshaped and refined its arsenal of coercive measures. In its recent practice, it has shifted away from imposing general economic sanctions on states and began to target specific individuals by imposing selective travel bans and the freezing of financial assets, ${ }^{16}$ while

9 About this changing notion of threats to peace, see J. E. Alvarez, International Organizations as Law-makers (2005), 195-196; see also K. C. Wellens, 'The UN Security Council and new threats to the peace: back to the future', (2003) 15 JCSL 15.

10 A prime example is Resolution S/RES/1373, 28 September 2001 in which the Council imposed a far-reaching set of obligations on all States to prevent providing terrorists a safe haven or any sustenance or support and denying any access to financial resources. In a similar vein, the Council adopted general resolutions regarding the prevention of proliferation of weapons of mass destruction, such as S/RES/1540, 28 April 2004.

11 See P. C. Szasz, 'The Security Council Starts Legislating', (2002) 96 AJIL 901; S. Talmon, 'The Security Council as World Legislature', (2005) 99 AJIL 175; M. Happold, 'Security Council Resolution 1373 and the Constitution of the United Nations', (2003) 16 LJIL 593.

12 Alvarez, op.cit., fn. 9, p. 196-197.

13 Established by S/RES/692, 20 May 1991. See also Section E of S/RES/687, 8 April 1991.

14 International Tribunal for the Prosecution of Persons Responsible for Serious Violations of International Humanitarian Law Committed in the Territory of Former Yugoslavia since 1991 (ICTY), established by S/RES/827, 25 May 1993.

15 International Criminal Tribunal for Rwanda (ICTR), established by S/RES/955, 8 November 1994.

16 See P. Wallensteen and C. Staibano, International Sanctions: Between Words and Wars in the Global System (2005). 
entrusting the implementation of these measures to sanction committees. ${ }^{17}$ Some of these committees administer extensive lists of individuals and entities, which has raised a number of fundamental legal questions, in particular, regarding the need to balance human rights and due process concerns on the one hand and the need for anti-terrorism measures on the other. Moreover, it raises the issue whether the Council starts to take on a semi-judicial role as well. ${ }^{18}$

In view of its important functions, there can be little doubt that the Security Council should be an organ of limited membership, capable of acting timely, decisively and with the power to enforce its decisions. This is especially important if the Council is to fulfil its role with regard to the emerging 'responsibility to protect' as entrusted to it by the world leaders at the September 2005 World Summit, when they pledged 'to take collective action ... through the Security Council ... should peaceful means be inadequate and national authorities are manifestly failing to protect their populations from genocide, war crimes, ethnic cleansing and crimes against humanity. ${ }^{, 19}$ The challenge is how to compose a Council sufficiently small for efficient and effective action and sufficiently large to be effective and its decisions to be legitimate.

\section{Criteria for the Composition of the Security Council}

Article 23 distinguishes permanent and elected members. As to the permanent members, the Charter lists five. They are often referred to as the Great Powers, although in reality they differ considerably on many scores such as population, economy, size of army or extent of power. It is striking that this Article 23 has never been amended, despite the fact that the Republic of China was replaced by the People's Republic of China in $1971^{20}$ and the Union of Soviet Socialist Republics by the Russian Federation in 1992.

As regards the elected members, there was one Charter amendment in 1963 expanding the number from six to 10 in order to provide for 'a more adequate geographical representation . . . and making it a more effective organ for carrying out its functions under the Charter of the United Nations' ${ }^{21}$ The two most relevant

17 Currently, there are 12 active sanction committees. See <http://www.un.org/Docs/sc/ committees/INTRO.htm $>$.

18 See Strengthening Targeted Sanctions Through Fair and Clear Procedures, annexed to A/60/887-S/2006/331, 14 June 2006.

19 World Summit Outcome Document, op.cit., fn. 1, para. 139. See also P. Hilpold, 'The Duty to Protect and the Reform of the United Nations - A New Step in the Development of International Law?', (2006) 10 Max Planck Yearbook of United Nations Law 35; and S.Breau, 'The Impact of the Responsibility to Protect on Peacekeeping', (2006) 11 JCSL 429-464.

20 See $U N Y B(1971)$ at $126-135$.

21 GA Res. 1991 (XVIII), 17 December 1963. The amendments entered into force on 31 August 1965; UNYB (1965) at 232. For a historical account of the Charter amendment process, and especially the ratification of the amendments by the P-5, see E. Luck, 'Reforming the United Nations: Lessons from a History in Progress', in J. E. Krasno 
criteria for the election of those members on the Council can still be found in the UN Charter itself. Article 23 stipulates that the non-permanent members be elected with due regard to, firstly, their contribution to the maintenance of peace and security and, secondly, equitable geographic distribution. ${ }^{22}$ As noted in a classic work on the UN: 'This was not meant to be a rigid or automatic formula, but rather, an indication of the factors the Assembly is expected to take into account in electing the non-permanent members of the Council. ${ }^{23}$

These criteria of contribution and distribution are closely related to other ones frequently used in the debate, such as democratisation, representativeness, legitimacy, efficiency, transparency and effectiveness. It is notable that Article 23 first mentions the capacity of the prospective member to contribute to the maintenance of international peace and security. However, in practice, the second criterion relating to geographical distribution has gained most weight throughout the period of the United Nations. Gentlemen's agreements were concluded as to the geographical distribution. The current one dates back to $1963^{24}$ and involves the following division among the five regional groupings that the UN often employs for election purposes: five from the African and Asian group; two from the Western European and other countries group; two from Latin America; and one from Eastern Europe. During the Cold War, the formula of 'equitable geographic distribution' sometimes led to very sharp clashes and gave rise to the question whether it referred to physical or rather political geography. ${ }^{25}$

Nevertheless, it would be wrong to assume that the first criterion regarding the member's contribution to the maintenance of international peace and security had been completely neglected. While geographic factors may have influenced

(ed.), The United Nations: Confronting the Challenges of a Global Society (2004) 359-398 at 366-368.

22 For a list of possible criteria considered during the discussions at San Francisco, see UNCIO, Documents, XI, at 676-677.

23 See L. M. Goodrich, E. Hambro, and A. P. Simons, The Charter of the United Nations: Commentary and Documents (1969) at 197. However, according to the Algerian professor Benchikh: 'Il est incontestable que l'article 23, contrairement à ce que semblent croire certains partisans de l'élargissement du Conseil de sécurité, établit une hiérarchie entre les deux critères de recrutement qu'il mentionne en faveur de la contribution au maintien de la paix et aux autres fins de l'Organisation.' M. Benchikh, 'Article 23', in J-P. Cot, A. Pellet and P. Tavernier, La Charte des Nations Unies: commentaire article par article (2005) 867-878 at 875. In his view, the criterion relates to the recruitment of nonpermanent members, taking into account their contribution to the maintenance of peace and security as well as to the purposes of the United Nations in the wider sense of Article 1 of the Charter.

24 The division was spelled out in the second part of the resolution adopting Charter amendments. See, op.cit., fn. 21.

25 The issue arose, for instance, when the General Assembly, against the usual practice, elected Greece (1952) and Turkey (1954) from the Eastern European region instead of a Communist government. See B. Conforti, The Law and Practice of the United Nations (2005) at 62. 
the frequent election of Argentina or Brazil to non-permanent seats, ${ }^{26}$ the first criterion may well explain why countries such as Canada, Pakistan and India (as major peace-keeping contributors) and Germany, Italy, Japan, Belgium and the Netherlands (as major financial contributors) have relatively frequently served on the Council. ${ }^{27}$ In this respect, it should also be noted that the High-level Panel on Threats, Challenges and Change called for a greater involvement in the work of the Council of those contributing most to the United Nations: 'specifically in terms of contributions to United Nations assessed budgets, participation in mandated peace operations, contributions to voluntary activities of the United Nations in the areas of security and development, and diplomatic activities in support of United Nations objectives and mandates.'28

While Article 23 generally did not give rise to controversies, at least on two occasions the General Assembly faced considerable problems in filling a vacancy on the Security Council. The first time was in 1979, when Cuba and Colombia competed for the non-permanent seat, but neither of them was able to secure a majority in the General Assembly. Only after the two contenders withdrew from their candidature in early 1980, Mexico was elected to the vacant seat. Nonetheless, the Security Council, for the first time in history, commenced its meetings in January 1980 short of its full complement, whereby a number of questions about the competence of the not-fully composed Council were raised. ${ }^{29}$ The story repeated itself in 2006 (and interestingly again in relation to the Latin American seat), when the two contenders, Guatemala and Venezuela, eventually after 47 ballots, had to resign in favour of Panama, which was elected as a consensus candidate to represent the region. ${ }^{30}$ Interestingly, one of the two unsuccessful contenders, Guatemala, justified its country's appropriateness by referring to its own past experience of a process of post-conflict peace-building and democratisation and to its recent contribution to UN peacekeeping and observer missions. ${ }^{31}$

26 Brazil and Argentina have served nine and eight times, respectively. See the list of countries that were elected members of the Security Council, available at: $<$ http://www.un.org/sc/list_eng5.asp > (last accessed on 20 November 2006).

27 Japan has served nine times, Canada, India, Italy and Pakistan six times, and Germany and Netherlands five times. Ibid.

28 The report adds that '[a]mong developed countries, achieving or making substantial progress towards the internationally agreed level of $0.7 \%$ of GNP for ODA (Official Development Assistance) should be considered an important criterion of contribution.' Report of the High-level Panel on Threats, Challenges and Change, A More Secure World: Our Shared Responsibility, chaired by Anand Panyarachun, UN doc. A/59/565, 29 November 2004, para. 249.

29 For a fuller account of the story and its legal implications, see W.M. Reisman, 'The Case of the Nonpermanent Vacancy', (1980) 74 AJIL 907-913.

30 See " "Tug-of-War" between Guatemala and Venezuela for Security Council Seat Loosens; Panama Steps In, Receives General Assembly Majority after 48 Secret Ballots', General Assembly press release GA/10528, 7 November 2006.

31 See article by the Minister of Foreign Affairs of Guatemala, Gert Rosenthal, 'Just let the best candidate win; Security Council Seat', International Herald Tribune, 24 October 2006 , at 7. 
Model A

\begin{tabular}{lccccc}
\hline Regional area & $\begin{array}{c}\text { Number } \\
\text { of } \\
\text { states }\end{array}$ & $\begin{array}{c}\text { Permanent } \\
\text { seats } \\
\text { (continuing) }\end{array}$ & $\begin{array}{c}\text { Proposed new } \\
\text { permanent } \\
\text { seats }\end{array}$ & $\begin{array}{c}\text { Proposed 2-year } \\
\text { (non-renewable) } \\
\text { seats }\end{array}$ & Total \\
\hline Africa & 53 & 0 & 2 & 4 & 6 \\
Asia and Pacific & 56 & 1 & 2 & 3 & 6 \\
Europe & 47 & 3 & 1 & 2 & 6 \\
Americas & 35 & 1 & 1 & 4 & 6 \\
Totals & 191 & 5 & 6 & 13 & 24 \\
\hline
\end{tabular}

Model B

\begin{tabular}{lccccc}
\hline Regional area & $\begin{array}{c}\text { Number } \\
\text { of } \\
\text { states }\end{array}$ & $\begin{array}{c}\text { Permanent } \\
\text { seats } \\
\text { (continuing) }\end{array}$ & $\begin{array}{c}\text { Proposed } \\
\text { 4-year } \\
\text { renewable } \\
\text { seats }\end{array}$ & $\begin{array}{c}\text { Proposed } \\
\text { 2-year } \\
\text { (non-renewable) } \\
\text { seats }\end{array}$ & Total \\
\hline Africa & 53 & 0 & 2 & 4 & 6 \\
Asia and Pacific & 56 & 1 & 2 & 3 & 6 \\
Europe & 47 & 3 & 2 & 1 & 6 \\
Americas & 35 & 1 & 2 & 3 & 6 \\
Totals & 191 & 5 & 8 & 11 & 24 \\
\hline
\end{tabular}

Source: A More Secure World, UN doc. A/59/565 (2004), pp. 67-68.

\section{Review of Recent Reform Proposals}

In its 2004 report $A$ More Secure World, ${ }^{32}$ the High-level Advisory Panel elaborated two alternative models for expansion of the membership of the UN Security Council. Both models would lead to a Council of 24 (rather than the current 15) members, with a distinction between four (rather than the current five) main regions in the world: Africa, Asia and the Pacific, Europe and the Americas. Model A envisaging six new permanent members (without veto) and three additional non-permanent members and model $\mathrm{B}$ envisaging eight new semi-permanent members with 4-year renewable terms and only one additional non-permanent seat. The proposal to enlarge the Council to 24 members is in line with the trend in other universal organisations to enlarge the size of their non-plenary organs. ${ }^{33}$

32 A More Secure World, op.cit., fn. 28.

33 See N. M. Blokker, 'Towards a Second Enlargement of the Security Council? A Comparative Perspective', in N. M. Blokker and N. J. Schrijver (eds.), The Security Council and the Use of Force (2005) 253-260. 
In his March 2005 report In Larger Freedom, ${ }^{34}$ Annan explicitly opened the option for any other viable solutions on which consensus might emerge. ${ }^{35}$ However, this proved ultimately not to be the case. Neither the so-called G-4 proposal $^{36}$ (tabled by the four large aspirants for permanent seats: Brazil, India, Japan and Germany) nor the 'Uniting for Consensus' proposal ${ }^{37}$ (tabled by a loose coalition of mostly middle powers who are the regional rivals of the states that would acquire permanent membership: Argentina, Canada, Italy, Mexico, Pakistan, Republic of Korea, Spain and Turkey; previously also known as the 'coffee club') gained sufficient support. The G-4 proposal purported to increase the membership of the Council from 15 to 25 by adding six permanent and four non-permanent members. Somewhat reluctantly, the G-4 proposed that the new permanent members were not to obtain the right of veto, but they would otherwise have the same responsibilities and obligations as the current permanent members. The 'Uniting for Consensus' proposal wanted to double the non-permanent seats from 10 to 20 , each serving on terms of 2 years. However, the proposal provides for the possibility of immediate re-election, subject to the decision of their respective geographical groups. ${ }^{38}$

\section{Some Alternative Ideas}

In the light of the stalemate on reform proposals, it may well be wise to pause and think, as to which alternative ways could be employed to improve the representativeness and effectiveness of the Council in the near future. First of all, one may wonder whether it is at all wise to expand the Council. As the former Dutch Ambassador to the UN, Peter van Walsum, noted in a recent commentary: 'No one can seriously believe a council with 24 members can be more effective than one with 15 , but it has become politically incorrect to point this out.' 39

Secondly, even in this multi-actor world, we seem to be caught in thinking of Security Council reform in terms of expanding its membership with more States. However, serious thought should be given to the proposition to change the membership of the Council drastically by allowing for representation by relevant regional associations, such as the European Union, the African Union, the Organisation of the Islamic Conference, the Association of South-East Asian

34 Kofi Annan, In Larger Freedom. Towards Development, Security and Human Rights for All, UN doc. A/59/2005, 21 March 2005.

35 'I urge Member States to consider the two options, models A and B . . . or any other viable proposals in terms of size and balance that have emerged on the basis of either model.' In Larger Freedom, op.cit., fn. 34, para. 170.

36 A/59/L.64, 6 July 2005, re-tabled as A/60/L.46, 9 January 2006.

37 A/59/L.68, 21 July 2005.

38 See also P. Hilpold, 'Reforming the United Nations: New Proposals in a Longlasting Endeavour', (2005) 52 Netherlands International Law Review 389-432.

39 P. van Walsum, 'A hitch could still stall the momentum in favour of a P-11 UN Security Council', Financial Times, 18 April 2005, at 14. 
Nations and the Organisation of American States. This could well be a proper way to give more substance to the two criteria of Article 23 -i.e. effectiveness and representativeness - and perhaps also give more impetus to the provisions of Article 52(2) requiring the member states to make every effort to achieve pacific settlement of local disputes through or by regional arrangements before referring them to the Security Council. In their turn, regional associations could then be expected to deepen their common security and foreign policy in order to ensure their representativeness for the region concerned as well as the effectiveness of the Council.

Drastic reform of the Security Council, on the other hand, may not necessarily be effected only by expanding the size of the Council. Much can be gained by improving transparency and accountability through other means, for example, by improving the working methods of the Council and institutionalising the co-operation of the Council with other principal UN organs as well as by strengthening the consultation with other relevant actors. It tends to be overlooked that an expanded Council will not be more democratic and representative unless its working methods provide for more transparency, accountability and inclusiveness. ${ }^{40}$ Besides, for most of the 192 member states, the improvement in the working methods of the Council would also have a more immediate impact than the necessarily modest change in its size and composition. ${ }^{41}$

Already during the 1990s, many informal improvements were introduced into the working methods of the Council, especially as regards the transparency and accountability of its deliberations. ${ }^{42}$ The impression, however, remained that the progress has not gone far enough and thus reform proposals continued to feature high on the agenda. It needs to be observed that both the G-4 43 and 'Uniting

${ }^{40}$ K. van Kesteren, 'Reforming the Security Council: Views from Practice', in N. M. Blokker and N. J. Schrijver (eds.), The Security Council and the Use of Force (2005) 261-268.

41 About the proposals on the improvement of working methods, see the study of E. C. Luck, 'Reforming the Security Council-Step One: Improving Working Methods', background paper prepared at the request of the Swiss Government and its Permanent Mission to the United Nations for discussion with UN Member States, 25 April 2005.

42 This included inter alia the introduction of meetings of council members with one or more independent experts for an exchange of views on a pressing issue before the Council (the Arria formula); participation of the Council in a number of retreats, away from headquarters; undertaking of missions to visit areas where developments are of particular interest or concern to the Council; meetings of the Council at foreign minister or summit level; briefing by the President of the Council to non-members, and often the press, on the results of informal and private consultations; provision of tentative monthly forecasts and provisional agendas for the Council's upcoming work, as well as provisional draft resolutions to non-members; more regular consultations among Security Council members and troop contributors, along with key secretariat officials; and participation of non-members in the Council's work on a more regular and substantive basis. See E. C. Luck, UN Security Council: Practice and Promise (2006) at 123-124.

43 The G-4 draft resolution (A/59/L.64, 6 July 2005, para. 8) proposed the following measures: more public meetings; regular consultation with non-members; granting non-members access to and participation in subsidiary organs; making draft resolutions 
for Consensus ${ }^{44}$ draft resolutions on Security Council reform included elaborate proposals on how to further improve the Council's working methods, although the World Summit Outcome Document eventually did not come further than recommending the Security Council to 'continue to adapt its working methods so as to increase the involvement of States not members of the Council in its work, as appropriate, enhance its accountability to the membership and increase the transparency of its work. ${ }^{45}$ In spite of the slow progress on Security Council reform, initiatives have not stalled, as evident from the recent draft resolution tabled by Costa Rica, Jordan, Liechtenstein, Singapore and Switzerland (S-5, i.e. group of five small countries), which specifically addresses the working methods of the Council. ${ }^{46}$ However, it is interesting to note that, while generally supportive of the draft resolution, some countries expressed the opinion that action on the working methods would dissipate the pressure for expansion. ${ }^{47}$

Most of the proposals presented so far, include the institutionalisation of the emerging practice of more open debates of the Council and in which experts can also be heard, briefings by the President of the Council to the press and structured consultations between the President of the Council with the Presidents of the General Assembly and the Economic and Social Council. Moreover, the strengthening of consultation with other relevant actors has been proposed. This is to be achieved by a more structural involvement of troop contributing States in the work of the Council (see also, Article 44 UN Charter), a better hearing of States affected by Security Council discussions and decisions, and a much improved co-operation with other international agencies; first of all, those within the UN system such as UNICEF, the World Food Programme and UN Development

and other draft documents available to non-members; providing frequent, timely and qualitative briefings for non-members on matters discussed within the Council; holding regular and timely consultations with troop-contributing countries and other countries concerned with peacekeeping operations; improving consultations with presidents of GA and Economic and Social Council (ECOSOC); providing substantive and comprehensive annual evaluation of the Council's work; and making use more frequently of special reports pursuant to article 24(3) of the Charter. These proposals have been reiterated in a more recent draft resolution on Security Council reform (A/60/L.46, 9 January 2006, para. 8).

44 The 'Uniting for Consensus' draft resolution (A/59/L.68 of 21 July 2005, para. 7) called for: restraint in the use of veto; procedures to guarantee transparency in decision-making, accountability in performance and access to information, including open briefings and interaction with all interested parties; consultation, cooperation and adequate exchange of information with the GA and ECOSOC; access and better participation of nonmembers of the Security Council; and adoption of formal rules of procedure.

45 World Summit Outcome Document, op.cit., fn. 1, para. 154.

46 See draft resolution on improving the working methods of the Security Council A/60/L.49 of 17 March 2006. The draft resolution outlines 19 recommendations, including measures for greater transparency over sanctions and peacekeeping operations and mechanisms to limit the use of the veto in cases of large-scale human rights abuse.

47 See Draft report of the Open-ended Working Group on the Question of Equitable Representation on and Increase in the Membership of the Security Council and Other Matters related to the Security Council, UN doc. A/AC.247/2006/L.1, 31 July 2006, at 6. 
Programme, but also specialised agencies such as the World Health Organisation, the World Bank group and regional associations. In view of the little chance for institutional change in the near future, such initiatives not requiring any amendments of the Charter may well prove to be the only feasible avenues in the years ahead, to better equip the Council in its pursuance of collective Security. ${ }^{48}$

48 See also the comment that 'political convergence precedes institutional change, not the other way around', E. Luck, 'How Not to Reform the United Nations', (2005) 11 Global Governance 407, at 410-411. 